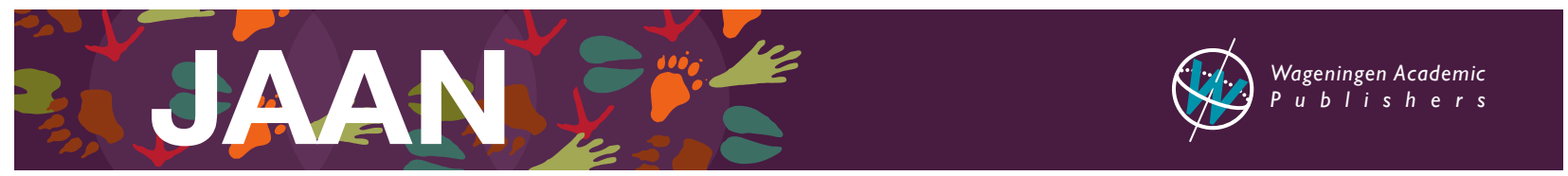

\title{
Effect of supplementing phytase on piglet performance, nutrient digestibility and bone mineralisation
}

\author{
C. De Cuyper ${ }^{1}$, L. Nollet ${ }^{2 *}$, M. Aluwé ${ }^{1}$, J. De Boever ${ }^{1}$, L. Douidah ${ }^{1}$, E. Vanderbeke ${ }^{2}$, N. Outchkourov ${ }^{3}$, S. Petkov ${ }^{3}$ \\ and S. Millet ${ }^{1}$ \\ ${ }^{1}$ ILVO (Flanders Research Institute for Agriculture, Fisheries and Food), Animal Sciences Unit, Scheldeweg 68, 9090 Melle, \\ Belgium; ${ }^{2}$ Huvepharma NV, Uitbreidingstraat 80, 2600 Antwerp, Belgium; ${ }^{3}$ Huvepharma EOOD, Nikolay Haytov Street \\ 3a, 1113 Sofia, Bulgaria; lode.nollet@huvepharma.com
}

Received: 18 December 2019 / Accepted: 2 March 2020

(c) 2020 C. De Cuyper et al.

RESEARCH ARTICLE

PIGS

\begin{abstract}
Incremental levels of the phytase, OptiPhos ${ }^{\bullet}$ Plus, were fed to 150 weaned piglets (five treatments of 30 pigs) to determine the effect on piglet performance, nutrient digestibility and bone mineralisation. Piglets were fed a basal diet from four to six weeks and a pre-starter diet from six to ten weeks of age. The basal diets contained reduced digestible phosphorus $(\mathrm{P})$ and calcium $(\mathrm{Ca})(1.5 \mathrm{~g} / \mathrm{kg}$ digestible $\mathrm{P}$, and $\mathrm{Ca} 5.5 \mathrm{~g} / \mathrm{kg}$ and $5.6 \mathrm{~g} / \mathrm{kg}$ for weaner and prestarter, respectively) to provide a negative control. Phytase was added at 0, 125, 250, 500 and 1000 phytase units (FTU)/kg feed. Faecal samples were collected at nine weeks of age and analysed for P, Ca and crude protein (CP) content to calculated digestibility. Metacarpal bone IV mineralisation was assessed by ash content and the weight and length of the bone. Incremental increases of phytase improved final body weight (BW) $(P<0.001)$, average daily gain $(\mathrm{ADG})(P<0.001)$ and feed conversion ratio $(\mathrm{FCR})(P<0.01)$. The statistical model predicted a linear increase for daily feed intake (DFI), ADG and BW with increased phytase increments. BW at the end of the trial increased by $824 \mathrm{~g}$ per increase of $250 \mathrm{FTU} / \mathrm{kg}(P<0.001)$. ADG and DFI increased by $19 \mathrm{~g} /$ day $(P<0.001)$ and 18 $\mathrm{g} /$ day $(P<0.05)$ respectively, per increase of $250 \mathrm{FTU} / \mathrm{kg}$. As the effect on ADG and final BW was higher at lowest doses, a quadratic effect for these parameters was observed, within the measured range of phytase levels $(P=0.029$ and 0.028 , respectively). A reduction of 0.03 in FCR was observed for each $250 \mathrm{FTU} / \mathrm{kg}$ increase $(P<0.01)$. For each increase in $250 \mathrm{FTU} / \mathrm{kg}$, bone dry weight increased by $131 \mathrm{~g}(P<0.05)$ and bone ash concentration by $1.9 \%$ of fat free dry matter $(P<0.001)$. The results showed that the addition of phytase to piglet diets low in $P$ led to better utilisation of phytate-P and consequently better piglet performance.
\end{abstract}

Keywords: phytase, piglets, phosphorous, digestibility, performance

\section{Introduction}

Phosphorus $(\mathrm{P})$ is an essential macro element that regulates the metabolic and physiological functions of a living organism. The P derived from plant components in the diet is only partly digestible by monogastric animals, because $\mathrm{P}$ is mainly stored in the form of phytate. Phytase enzymes are used in animal feeds to release $\mathrm{P}$ from phytate, and have been used commercially since the 1990s in both pig and poultry diets. Initially, phytase was added to reduce $\mathrm{P}$ excretion in litter and faecal material, although research has shown the enzyme could spare other nutrients in the diet, as phytate binds protein and various minerals, and has been shown to interfere with natural enzyme secretion activity (Selle et al., 2012). Moreover, as an essential nutrient, especially for growing animals, $\mathrm{P}$ is one of the most expensive feed components when provided as inorganic form of phosphates (30-50\% of total P) and inclusion of phytase can reduce the inclusion of phosphates, leading to a financial benefit. 
Positive effects with the application of exogenous phytase of different types and at various levels (FTU/kg) have been reported over the years. The first commercially available phytase was 3-phytase derived from Aspergillus niger, but in the last two decades, 6-phytase originating from Escherichia coli, Peniophora, Citrobacter, or Buttiauxella spp. have become commercially available. Phytase has been shown to improve performance, nutrient digestibility (ileal and faecal) and bone mineralisation in piglets and pigs in a dose responsive way (Dersjant-Li et al., 2017; Kühn et al., 2016; Kühn and Partanen, 2012; Torrallardona and Ader, 2016).

Commercial phytases can have different efficacies, but there are no standardised trial protocols to assess their potency, which makes it difficult to compare efficiency. Comparison of phytases at different inclusion levels has been mainly done in poultry (Leyva-Jiminez et al., 2019) while, in pigs, the smaller size of trial facilities limits such research. However, some publications exist on the topic. In a trial conducted by Guggenbuhl et al. (2016), starter and grower-finisher pigs were used to compare three phytases at varying inclusion levels. All three commercial phytases improved average daily gain (ADG), but effective levels differed in both piglets and grower-finisher pigs.

The effective inclusion rates for phytase has been the subject of much scrutiny, especially as the price of inorganic $P$ sources has increased considerably in the last decade, and there has been a need for increased use of phytase to keep feed formulations economically viable. In a review (Dersjant-Li et al., 2015) dose response was examined in detail, and showed less than $60 \%$ phytate breakdown in the gut of pigs when 'standard' levels of 500 phytase units (FTU) were applied per kg of feed, and that higher doses were much more effective. Recently, it has been observed that the level and the source of calcium $(\mathrm{Ca})$ has an impact on the efficiency of phytase in pigs, which means that this should be considered when evaluating the enzyme (Schlegel and Gutzwiller, 2016).

The aim of this study was to evaluate increasing levels of a novel 6-phytase derived from the E. coli appA2 gene (Huvepharma, Belgium) at levels of 0, 125, 250, 500 and $1000 \mathrm{FTU} / \mathrm{kg}$ in the diet of piglets to determine the effects on performance, apparent total tract digestibility of $\mathrm{Ca}, \mathrm{P}$ and crude protein (CP) and bone mineralisation.

\section{Materials and methods}

The experiment was approved by the Ethical Committee for the use of Animals in Feeding Studies at the Flanders Research Institute for Agriculture, Fisheries and Food (ILVO), Animal Sciences Unit, Belgium (ILVO; EC2018/326).

\section{Animals}

In total, 150 piglets (male and female) obtained from crossing a Piétrain boar and a RA-SE genetics hybrid sow were used in this experiment. In one weaning round, six pens (three containing five barrows and three containing five gilts) were allocated to each of the five dietary treatments at weaning (four weeks of age; average body weight (BW) $8.2 \mathrm{~kg}$ ), giving 30 pigs per treatment. All pigs were ear tagged for individual identification. The pens measured $1 \mathrm{~m} \times 1.8 \mathrm{~m}$ to give $0.36 \mathrm{~m}^{2} / \mathrm{pig}$.

\section{Feeds and treatments}

The trial compared five dietary treatments. The piglets received the weaner diets from four to six weeks of age and the pre-starter diets between six and 10 weeks of age. Feed and water were provided ad libitum throughout the study. Each diet was produced from the same batch of basal feed, and differed in the presence or absence and the concentration of the phytase (OptiPhos ${ }^{\oplus}$ Plus) developed from the appA2 gene from $E$. coli as described in Rodriguez et al. (1999) and expressed in Komatagaella phaffii (Huvepharma, Belgium). The five treatment diets were denoted T1: no added phytase (negative control diet), T2: 125 FTU/kg, T3: 250 FTU/kg, T4: 500 FTU/kg, T5: $1000 \mathrm{FTU} / \mathrm{kg}$. The basal diet (T1) was reduced to $1.5 \mathrm{~g}$ digestible $\mathrm{P}$ in both weaner and pre-starter feed to create a deficiency, while Ca levels were maintained at 5.5 and 5.6 $\mathrm{g} / \mathrm{kg}$ for weaner and pre-starter feed respectively. Then, the basal feed batch was divided into five equal parts, and the four enzyme doses were premixed with $50 \mathrm{~kg}$ of feed before being added and mixed into the basal diet to obtain the respective concentrations. All diets were provided in pelleted form. A digestibility marker $(0.5 \%$ titanium oxide; $\mathrm{TiO}_{2}$ ) was included in the pre-starter diet. The diets were formulated to meet commercial recommendations (CVB, 2016) except for digestible $\mathrm{P}$ and $\mathrm{Ca}$, and were produced by ILVO Belgium. The basal composition is shown below (Table 1).

\section{Performance}

Piglets were monitored daily to record health, mortality and performance. Piglets were weighed individually at the start of the trial (at four weeks of age) and at the end of the experimental feeding period ( 10 weeks of age). The feed intake per pen was recorded at the same time points and average daily feed intake (DFI) was calculated. Feed conversion ratio (FCR) was calculated per pen.

\section{Faecal collection}

During the fifth week of the trial (when piglets were nine weeks old), faecal samples from the rectum were collected daily from two randomly selected piglets per pen for four 
Table 1. Ingredient composition of the basal diets (\%).

\begin{tabular}{lcc} 
Ingredient & Weaner & Pre-starter \\
Barley & 40.0 & 40.0 \\
Maize & 19.9 & 19.4 \\
Toasted soybeans & 10.0 & 5.0 \\
Soybean meal & 8.0 & 12.5 \\
Premix & 6.0 & 6.0 \\
Wheat middlings & 4.9 & 3.3 \\
Beet molasses & 3.0 & 3.0 \\
Rapeseed meal & 2.7 & 5.0 \\
Vegetable fat & 1.7 & 2.9 \\
Potato protein & 1.2 & - \\
Limestone & 1.0 & 1.0 \\
L-lysine HCl & 0.48 & 0.43 \\
Salt & 0.48 & 0.40 \\
L-threonine & 0.21 & 0.18 \\
DL-methionine & 0.20 & 0.18 \\
L-valine & 0.14 & 0.10 \\
L-tryptophan & 0.07 & 0.06 \\
Monocalcium phosphate & 0.01 & - \\
Titanium oxide marker & - & 0.50 \\
Sodium bicarbonate & - & 0.03 \\
\hline
\end{tabular}

1 Premix containing $80 \%$ dairy products and $20 \%$ vitamin and mineral premix providing the following quantities of vitamins and minerals per kilogram of diet: 15,000 IU vitamin A, 2,000 IU vitamin D3, $100 \mathrm{mg}$ vitamin E, $2 \mathrm{mg}$ vitamin $\mathrm{K}$ $2.5 \mathrm{mg}$ vitamin $\mathrm{B} 1,7.5 \mathrm{mg}$ vitamin $\mathrm{B} 2,20 \mathrm{mg}$ vitamin $\mathrm{B} 5,5 \mathrm{mg}$ vitamin $\mathrm{B} 6,0.04$ $\mathrm{mg}$ vitamin B12, $100 \mathrm{mg}$ vitamin C, $30 \mathrm{mg}$ niacin, $324 \mathrm{mg}$ choline, $3 \mathrm{mg}$ folic acid, $0.15 \mathrm{mg}$ biotin, $516 \mathrm{mg} \mathrm{Ca}, 419 \mathrm{mg} \mathrm{P}, 165 \mathrm{mg}, 353 \mathrm{mg} \mathrm{Na}, 1,375 \mathrm{mg} \mathrm{Cl}$, 1,227 mg K, 234 mg S, 100 mg Fe, 160 mg Cu, 60 mg Mn, 100 mg Zn, 2 mg I, and $0.4 \mathrm{mg} \mathrm{Se}$.

consecutive days and frozen at $-20{ }^{\circ} \mathrm{C}$. The samples were pooled per pen, freeze-dried, ground and stored ready for analysis.

\section{Determination of bone parameters}

Four days after the final weighing at 10 weeks of age (pre-starter feeding was continued), one piglet (closest to the average pen BW) per pen was euthanised to assess the effect of the dietary treatments on bone quality. The right front feet from the animal was excised and stored at $-20{ }^{\circ} \mathrm{C}$. Frozen feet were placed in a beaker $(500 \mathrm{ml})$ filled with warm water with the claws upwards to prevent charring of the metacarpal bones. The beaker was then placed in a warm water bath $\left(75^{\circ} \mathrm{C}\right)$ to soak for 24 hours. After 24 hours, the metacarpal bone IV was collected and surrounding tissue removed. The bone was weighed, oven dried for 16.45 hours at $65^{\circ} \mathrm{C}$, and reweighed. The length of metacarpus IV (interior side) was measured using digital callipers. The metacarpal bone was gently cracked and stored at $-20^{\circ} \mathrm{C}$. The cracked metacarpal bone was defatted by extraction with petroleum ether (boiling point $40-60^{\circ} \mathrm{C}$, ISO 6492A), dried at $103{ }^{\circ} \mathrm{C}$ and incinerated at $650{ }^{\circ} \mathrm{C}$ to constant weight according to the methodology described by Bikker et al. (2013). The ash content of the fat free dry matter was calculated based on the weighed bone before and after incineration.

\section{Analysis}

Feed and faecal samples were ground through a $1 \mathrm{~mm}$ screen and analysed using accredited methods at the Animalab of ILVO-Animal Sciences Unit, Belgium. Crude protein $(\mathrm{N} \times 6.25)$ was determined according to Kjeldahl (ISO, 2009a), $\mathrm{TiO}_{2}$ by colorimetry (Myers et al., 2004), phytate P by the method of Haug and Lantzsch (1983) and total $\mathrm{Ca}$ and $\mathrm{P}$ by inductively coupled plasma optical emission spectrometry (ICP-OES, Agilent 5110 VDV, Agilent Technologies, Inc., Santa Clara, CA, USA). Moisture was determined by drying at $103^{\circ} \mathrm{C}(\mathrm{EC}, 1971)$, crude ash was obtained by incineration at $550{ }^{\circ} \mathrm{C}$ (ISO, 2002), crude fat was extracted with petroleum ether after hydrolysis with $\mathrm{HCl}$ (ISO, 1999), crude fibre was obtained using an Ankom Fiber Analyser (Ankom Technology, Macedon NY, USA) after boiling subsequently with sulphuric acid and sodium hydroxide (EC, 1992). The results of the feed analysis are shown in Table 2 and were in line with the calculated nutrient composition.

The final trial diets were analysed at Biovet JSC (Sofia, Bulgaria) for phytase activity (ISO, 2009b). A small amount was found in the negative control diets due to endogenous phytase from feed ingredients (Table 3). The actual included levels were then corrected for this endogenous activity, and were higher than expected. However, control of the good manufacturing procedure for feed production showed that the right amount of phytase was added to each treatment. It is well known that phytase analysis can provide quite variable results particular at lower levels. For instance, two collaborative studies between 14 (study 1) and 13 (study 2) laboratories to validate a colorimetric assay for determination of microbial phytase activity in feed at levels of 200 to $400 \mathrm{FTU} / \mathrm{kg}$ (in different types of feed) showed that reproducibility relative standard deviation values ranged from 14.1 to $27.6 \%$ in study 1 and 14.0 to $20.5 \%$ in study 2 (Engelen et al., 2001).

\section{Apparent total tract digestibility}

Faeces and feeds were analysed for $\mathrm{Ca}, \mathrm{P}, \mathrm{CP}$ and $\mathrm{TiO}_{2}$ as external marker for deriving digestibility. The faecal digestibility coefficients (\%) were calculated using the following formula:

$100 \times\left(1-\left(\frac{\text { Nutrient }_{\text {faeces }}}{\text { Nutrient }_{\text {feed }}} \times \frac{\mathrm{TiO}_{2 \text { feed }}}{\mathrm{TiO}_{2 \text { faeces }}}\right)\right)$

\section{Statistical analysis}

Statistical analysis was performed using R (R Core Team, 2017). Each pen was considered as an experimental unit. A linear and quadratic dose-response model was fitted with the supplemented phytase as independent continuous variable $(0,125,250,500$ and $1000 \mathrm{FTU} / \mathrm{kg})$, and used to 
Table 2. Calculated and analysed nutrient composition of the basal diets $\left(\mathrm{g} / \mathrm{kg}\right.$ unless otherwise stated). ${ }^{1}$

\begin{tabular}{|c|c|c|c|c|}
\hline \multirow[t]{2}{*}{ Nutrient ${ }^{2}$} & \multicolumn{2}{|c|}{ Calculated } & \multicolumn{2}{|c|}{ Analysed } \\
\hline & Weaner & Pre-starter & Weaner & Pre-starter \\
\hline Dry matter & 889 & 885 & 899 & 899 \\
\hline Crude protein & 170 & 167 & 178 & 171 \\
\hline Crude fat & 60 & 63 & 64 & 67 \\
\hline Crude ash & 50 & 55 & 48 & 53 \\
\hline Crude fibre & 38 & 40 & 43 & 46 \\
\hline Starch & 330 & 324 & & \\
\hline Sugars & 82 & 83 & & \\
\hline $\mathrm{Na}$ & 2.4 & 2.2 & & \\
\hline K & 9.6 & 9.7 & & \\
\hline $\mathrm{Cl}$ & 6.2 & 5.6 & & \\
\hline $\mathrm{Ca}$ & 5.5 & 5.6 & 5.4 & 5.7 \\
\hline $\mathrm{P}$ & 4.4 & 4.4 & 4.2 & 4.2 \\
\hline Dig. $P$ & 1.5 & 1.5 & & \\
\hline iP & 2.7 & 2.7 & 2.8 & 2.8 \\
\hline LYS & 11.9 & 11.3 & & \\
\hline SID LYS & 10.5 & 10.0 & & \\
\hline SID M+C/LYS & 0.6 & 0.6 & & \\
\hline SID THR/LYS & 0.7 & 0.7 & & \\
\hline SID TRP/LYS & 0.2 & 0.2 & & \\
\hline SID ILE/LYS & 0.5 & 0.5 & & \\
\hline SID LEU/LYS & 1.0 & 1.0 & & \\
\hline SID VAL/LYS & 0.7 & 0.7 & & \\
\hline SID HIS/LYS & 0.3 & 0.4 & & \\
\hline NEp (MJ/kg) & 9.9 & 9.9 & & \\
\hline
\end{tabular}

${ }^{1}$ Calculated values based on CVB, 2007. The average analysed nutrient composition of the diets was used to calculate digestibility (as the basal negative control diet was produced first before supplementation of OptiPhos ${ }^{\circledR}$ Plus).

${ }^{2}$ Dig. $P=$ apparent faecal digestible $P ;$ iP = phytate-P, SID = standardised ileal digestible, NEp = net energy pig (CVB, 2007).

Table 3. Phytase levels (background and supplemental) in the diets.

$\begin{array}{llccc}\text { Treatment } & \text { Phase }^{1} & \text { Expected (FTU/kg) } & \text { Analysed (FTU/kg) } & \text { Corrected for endogenous activity (FTU/kg) } \\ \text { T1 } & \text { W } & 0 & 70 & 0 \\ \text { T2 } & \text { P } & & 85 & 0 \\ & \text { W } & 125 & 320 & 250 \\ \text { T3 } & \text { P } & & 365 & 280 \\ & \text { W } & 250 & 540 & 470 \\ \text { T4 } & \text { W } & & 470 & 385 \\ & \text { W } & 500 & 760 & 690 \\ \text { T5 } & \text { W } & 1000 & 780 & 695 \\ & \text { P } & & 1,240 & 1,170 \\ & & 1,210 & 1,125\end{array}$

${ }^{1} \mathrm{P}=$ pre-starter diet; $\mathrm{W}=$ weaner diet.

calculate the responses per increment of phytase added to feed. Bodyweight at the start (for analysis of performance) or bodyweight at the end (for analysis of bone mineralisation) were considered as covariables. Results were considered as significant where $P<0.05$.

\section{Results and discussion}

During the trial, one piglet in the T3 diet group died in the weaner phase, and three piglets (one each from treatments T1, T2 and T4) died in the pre-starter phase. This was not related to the dietary treatment. At the end of the trial, some joint stiffness was observed at levels of $38,3,0,3$, and $0 \%$ in piglets in T1, T2, T3, T4 and T5 fed groups, respectively. This problem was highest in piglets receiving the negative control diet (T1) with reduced P levels, and improved with the addition of phytase in all the other groups.

Across the whole trial period, the statistical model predicted a linear increase for DFI, ADG and BW with rising levels of phytase (from 0 to $1000 \mathrm{FTU} / \mathrm{kg}$; Table 4, Figure 1). BW at the end of the trial increased by $824 \mathrm{~g}$ per increase of 250 FTU/kg feed of phytase $(P<0.001)$. ADG and DFI followed the same pattern, increasing by $19 \mathrm{~g} /$ day $(P<0.001)$ and 18 g/day $(P<0.05)$ per increase of $250 \mathrm{FTU} / \mathrm{kg}$ feed of phytase, respectively). In addition, as the effect on ADG and final BW was slightly higher at the lowest doses, with diminishing effect on higher doses, a significant quadratic effect for these parameters was observed, within the measured range of phytase levels in this study $(P=0.029$ and $P=0.028$, 
Table 4. Effect of feeding graded levels of phytase on piglet growth performance from four to ten weeks of age.

\begin{tabular}{|c|c|c|c|c|c|c|c|c|c|}
\hline \multirow[t]{2}{*}{ Variable $^{1}$} & & \multirow[t]{2}{*}{$\mathrm{T} 1$} & \multirow[t]{2}{*}{ T2 } & \multirow[t]{2}{*}{ T3 } & \multirow[t]{2}{*}{ T4 } & \multirow[t]{2}{*}{ T5 } & \multirow[t]{2}{*}{$\mathrm{SEM}^{2}$} & \multicolumn{2}{|l|}{$P$-value } \\
\hline & & & & & & & & Linear & Quadratic \\
\hline $\begin{array}{l}\text { BW at end } \\
\text { ADG } \\
\text { DFI } \\
\text { FCR }\end{array}$ & $\begin{array}{l}\mathrm{kg} \\
\text { g/day } \\
\text { g/day }\end{array}$ & $\begin{array}{l}23.3 \\
351 \\
567 \\
1.61\end{array}$ & $\begin{array}{l}25.4 \\
400 \\
650 \\
1.63\end{array}$ & $\begin{array}{l}24.9 \\
387 \\
603 \\
1.56\end{array}$ & $\begin{array}{l}27.2 \\
440 \\
677 \\
1.54\end{array}$ & $\begin{array}{l}26.9 \\
436 \\
657 \\
1.51\end{array}$ & $\begin{array}{l}0.94 \\
16.2 \\
21.9 \\
0.03\end{array}$ & $\begin{array}{r}<0.001 \\
<0.001 \\
0.017 \\
0.007\end{array}$ & $\begin{array}{l}0.028 \\
0.029 \\
0.054 \\
0.530\end{array}$ \\
\hline
\end{tabular}

${ }^{1} \mathrm{ADG}=$ average daily gain; $\mathrm{BW}=$ bodyweight; $\mathrm{DFI}=$ daily feed intake; $\mathrm{FCR}=$ feed conversion ratio.

$2 \mathrm{SEM}=$ mean of the standard errors.
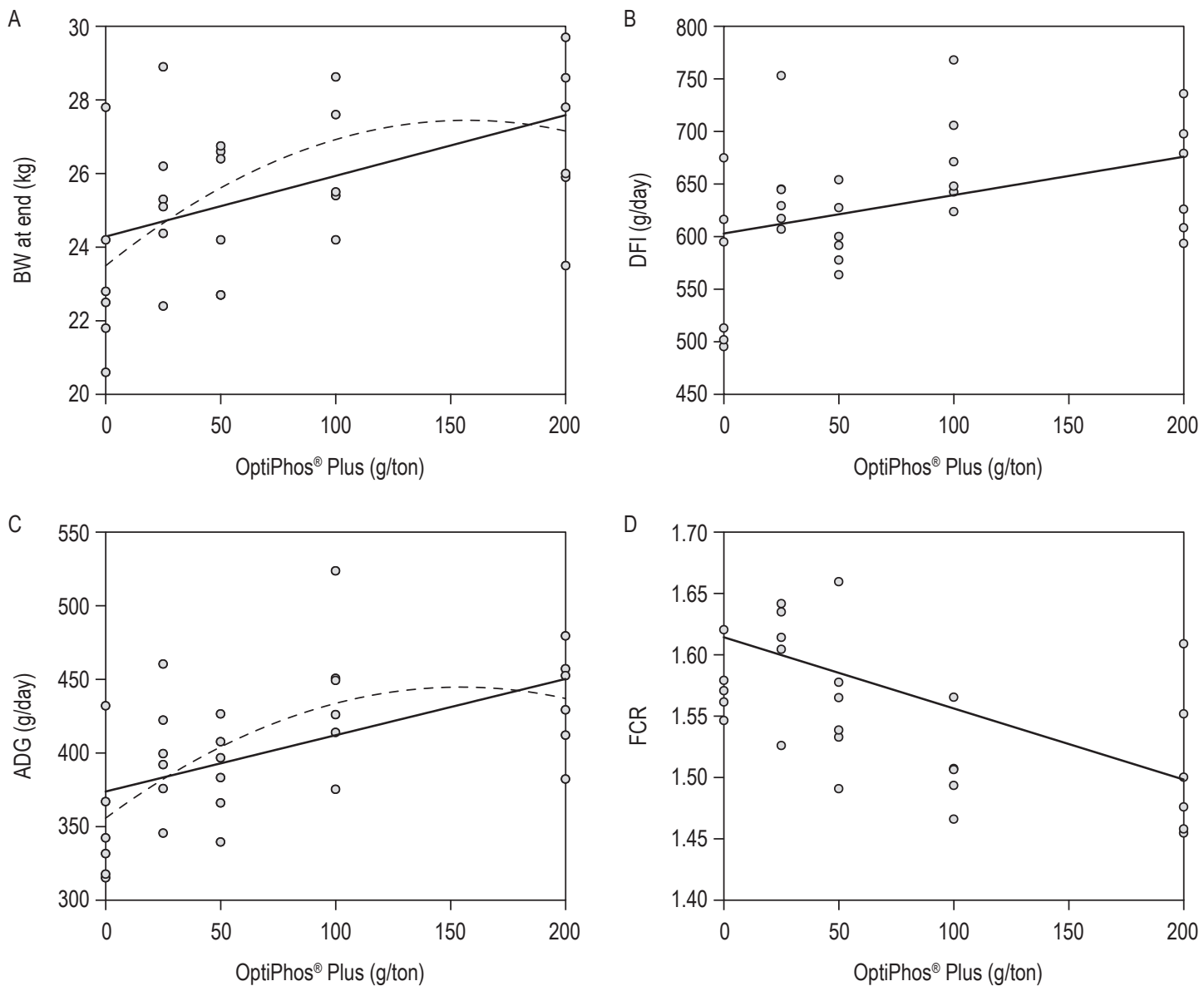

Figure 1. Piglet growth performance in function of increasing phytase level. Performance parameters (A) bodyweight (BW) at end; (B) daily feed intake (DFI); (C) daily gain (ADG); and (D) feed conversion ratio (FCR), from four to ten weeks of age are presented. Circles represent different pens, lines represent different models (full line, linear model; dashed line, quadratic model).

respectively). A reduction of 0.03 in FCR was observed per increase of phytase level with $250 \mathrm{FTU} / \mathrm{kg}$ feed $(P<0.01$; Table 4, Figure 1).

These results were in agreement with the findings reported by Dersjant-Li et al. (2017), who found that supplementation with 500, 1000 and 2,000 FTU/kg Buttiauxella phytase in a $P$ and $\mathrm{Ca}$-deficient diet $(1.5 \mathrm{~g} / \mathrm{kg})$ increased ADG and gain to feed (G:F) ratio in piglets 14 days post weaning.
This result had been previously observed by Zeng et al. (2015), who found that supplementation with 500, 1000 and 20,000 FTU/kg Buttiauxella phytase to a feed reduced in Ca and total P $(-1.6 \mathrm{~g} / \mathrm{kg})$ linearly improved ADG and reduced feed:gain ratio in a four-week feeding trial. Over a six-week trial using weaned piglets, Torrallardona and Ader (2016) statistically confirmed significant linear responses for the addition of phytase $(125,250500$ and $1000 \mathrm{FTU} /$ $\mathrm{kg})$ on ADG $(P<0.001)$, DFI $(P<0.01)$ and $\mathrm{G}$ :F $(P<0.05)$ in 
a feed reduced to 1.7 to $1.9 \mathrm{~g} \mathrm{P}$ per $\mathrm{kg}$. The performance improvements seen in the current trial and from published data can be attributed to the release of phytate-bound $\mathrm{P}$ replacing the deficient levels in the negative control diet. This trial did not have a positive control diet (e.g. where $P$ levels were present at adequate quantities), however other studies (Dersjant-Li et al., 2017; Torrallardona and Ader, 2016; Zeng et al., 2015) showed that phytasesupplementation regained the performance lost in the negative control diet back to match the performance seen in the positive control diets.

The digestibility results for each of the five treatment diets are shown below in Table 5. Apparent total tract digestibility (ATTD) of P, Ca and CP linearly improved with increasing levels of phytase (0 to $1000 \mathrm{FTU} / \mathrm{kg}$ feed). From the regression analysis, each increase of $250 \mathrm{FTU} / \mathrm{kg}$ phytase resulted in an increase of 6.5, 2.8 and $0.4 \%$ in ATTD of P $(P<0.001), \mathrm{Ca}(P=0.005)$ and $\mathrm{CP}(P<0.05)$, respectively. For $P$, a quadratic effect could be observed $(P=0.005)$, indicating a diminishing response with increasing doses.

These findings were in agreement with other trials (Dersjant-Li et al., 2017; Guggenbuhl et al., 2016; Kuhn and Partanen, 2012; Rutherfurd et al., 2014). In a trial using 6-phytase supplementation at levels of 250, 500, 1000 and 2,000 FTU/kg feed, Velayudhan et al. (2015) showed a significant increase in ATTD of Ca and P of $18.2,30.4,24.5$ and $33.8 \%$ and $46.8,98.4,99.7$ and $125.3 \%$ respectively with increasing phytase inclusion $(P<0.05)$. In their trial, a significant increase in $\mathrm{CP}$ digestibility was noted at all inclusion levels, which was not the case in the current trial. A higher, but not significant, ATTD for CP was observed by Zeng et al. (2015) in weaned piglets, using the same phytase at 500 and $1000 \mathrm{FTU} / \mathrm{kg}$ as Velayudhan et al. (2015). However, in the study by Zeng et al. (2015), phytase significantly increased ATTD of Ca from 46.0 to 60.7\% and ATTD of P from 37.7 to $59.3 \%$ at an inclusion level of $1000 \mathrm{FTU} / \mathrm{kg}$. The higher Ca digestibility due to phytase could be linked to the liberation of Ca complexed on the phytate molecule (Rutherford et al., 2014).

\section{Bone mineralisation}

A treatment effect was observed in the dry weight and crude ash of the metacarpus IV (right front leg), whereby bone weights and ash concentrations linearly increased as phytase level increased from 0 to $1000 \mathrm{FTU} / \mathrm{kg}$ feed (Table 6). From the regression analysis, each increase of $250 \mathrm{FTU} / \mathrm{kg}$ feed of phytase increased bone dry weight by $131 \mathrm{~g}(P<0.05)$ and ash concentration by $1.9 \%$ fat free dry matter $(P<0.001)$. For dry weight, a quadratic effect was observed $(P=0.013)$, indicating a diminishing response with increasing doses. A quadratic effect of treatment on bone length was observed $(P=0.014)$.

The effect on bone development was logical, considering the increased digestibility of $\mathrm{P}$ and $\mathrm{Ca}$ (Table 5), and was in line with other research, whether assessed in metacarpal bones (Gourley et al., 2018; Torrallardana and Ader, 2016; Zeng et al., 2015) or any other part of the skeleton as e.g. ribs (Kühn et al., 2016). As supplementation with phytase had no effect on fresh weight of the bone, it appeared that $\mathrm{Ca}$ and $\mathrm{P}$ deficiency resulted in a lower dry matter content

Table 5. Apparent total tract digestibility of phosphorus $(\mathrm{P})$, calcium $(\mathrm{Ca})$ and crude protein for piglets fed increasing levels of phytase in a low $\mathrm{P}$ control diet.

\begin{tabular}{|c|c|c|c|c|c|c|c|c|}
\hline \multirow[t]{2}{*}{ Variable } & \multirow[t]{2}{*}{$\mathrm{T} 1$} & \multirow[t]{2}{*}{$\mathrm{T} 2$} & \multirow[t]{2}{*}{ T3 } & \multirow[t]{2}{*}{ T4 } & \multirow[t]{2}{*}{ T5 } & \multirow[t]{2}{*}{ SEM $^{1}$} & \multicolumn{2}{|l|}{$P$-value } \\
\hline & & & & & & & Linear & Quadratic \\
\hline$P$ & 33.1 & 42.0 & 47.6 & 53.6 & 61.6 & 1.81 & $<0.001$ & 0.005 \\
\hline $\mathrm{Ca}$ & 52.5 & 56.0 & 60.2 & 59.4 & 65.2 & 2.56 & 0.005 & 0.542 \\
\hline Crude protein & 79.5 & 79.9 & 80.6 & 80.5 & 81.2 & 0.54 & 0.041 & 0.623 \\
\hline
\end{tabular}

${ }^{1} \mathrm{SEM}=$ mean of the standard errors.

Table 6. Metacarpal bone parameters (metacarpus IV, right front leg).

\begin{tabular}{|c|c|c|c|c|c|c|c|c|c|}
\hline \multirow[t]{2}{*}{ Variable } & & \multirow[t]{2}{*}{$\mathrm{T} 1$} & \multirow[t]{2}{*}{$\mathrm{T} 2$} & \multirow[t]{2}{*}{ T3 } & \multirow[t]{2}{*}{$\mathrm{T} 4$} & \multirow[t]{2}{*}{ T5 } & \multirow[t]{2}{*}{ SEM $^{1}$} & \multicolumn{2}{|l|}{$P$-value } \\
\hline & & & & & & & & Linear & Quadratic \\
\hline Fresh weight & $\mathrm{g}$ & 7.4 & 7.9 & 7.9 & 8.3 & 8.1 & 0.24 & 0.993 & 0.308 \\
\hline Dry weight & $\mathrm{g}$ & 3.8 & 4.4 & 4.6 & 5.0 & 4.9 & 0.17 & 0.042 & 0.013 \\
\hline Bone length & $\mathrm{mm}$ & 49.1 & 51.2 & 52.0 & 52.5 & 52.0 & 0.61 & 0.363 & 0.014 \\
\hline Crude ash & $\%$ FFDM ${ }^{2}$ & 44.2 & 45.4 & 47.9 & 49.4 & 52.4 & 0.60 & $<0.001$ & 0.108 \\
\hline
\end{tabular}

${ }^{1} \mathrm{SEM}=$ mean of the standard errors

${ }^{2}$ FFDM $=$ fat free dry matter. 
in the bone, while phytase supplementation led to better mineralisation of the bone and, thereby, improved bone strength.

\section{Conclusions}

Increasing the dietary level of phytase (OptiPhos ${ }^{\oplus}$ Plus) in graded levels up to $1000 \mathrm{FTU} / \mathrm{kg}$ linearly improved growth performance (BW, ADG, DFI and FCR), which was attributed to a linearly increased digestibility of $\mathrm{P}, \mathrm{Ca}$ and CP. This resulted in better bone mineralisation (dry weight and crude ash concentration) in comparison to a down-specified $\mathrm{Ca}$ and $\mathrm{P}$ negative control diet.

\section{References}

Bikker, P., Jongbloed, A.W., Van Krimpen, M.M., Dekker, R.A., Van Diepen, J.T.M. and Millet, M., 2013. Phosphorus requirements and retention in entire male and female pigs, a dose-response study. In: Book of Abstracts of the $64^{\text {th }}$ Annual Meeting of the European Federation of Animal Science, 26-30 August 2013, Nantes, France. Wageningen Academic Publishers, Wageningen, the Netherlands, p. 558.

Centraal Veevoederbureau (CVB), 2007. Veevoedertabel 2007: chemische samenstellingen en nutritionele waarden van voedermiddelen. Federatie Nederlandse Diervoederketen, Wageningen, the Netherlands.

Centraal Veevoederbureau (CVB), 2016. Tabellenboek veevoeding varkens 2016: voedernormen varkens en voederwaarden voedermiddelen voor varkens. Federatie Nederlandse Diervoederketen, Wageningen, the Netherlands, 35 pp. Available at: https://tinyurl. com/ql8j72b.

Dersjant-Li, Y., Awati, A., Schulze, H. and Partridge, G., 2015. Phytase in non-ruminant animal nutrition: a critical review on phytase activities in the gastrointestinal tract and influencing factors. Journal of the Science of Food and Agriculture 95: 878-896.

Dersjant-Li, Y., Wealleans, A.L., Barnard, L.P. and Lane, S., 2017. Effect of increasing Buttiauxella phytase dose on nutrient digestibility and performance in weaned piglets fed corn or wheat based diets. Animal Feed Science and Technology 234: 101-109.

Engelen, A.J., Van Der Heeft, F.C, Randsdorp, P.H.G., Somers, W.A.C., Schaefer, J. and Van der Vat B.J.C., 2001. Determination of phytase activity in feed by a calormetic enzymatic method; collaborative interlaboratory study. Journal of AOAC Internatioinal 84: 629-633.

European Commission (EC). 1971. Determination of moisture. Official Journal of the European Communities L279: 3-5.

European Commission (EC). 1992. Determination of crude fibre. Official Journal of the European Communities L344 35-37.

Gourley, K.M., Woodworth, J.C., DeRouchey, J.M., Dritz, S.S., Tokach, M.D. and Goodband R.D., 2018. Determining the available phosphorus release of Natuphos E 5,000 G phytase for nursery pigs. Journal of Animal Science 96: 1101-1107.

Guggenbuhl, P., Calvo, E.P. and Fru, F., 2016. Effect of high dietary doses of a bacterial 6-phytase in piglets fed a corn-soybean meal diet. Journal of Animal Science 94(suppl_3): 307-309.
Haug, W. and Lantzsch, H.J., 1983. Sensitive method for the rapid determination of phytate in cereals and cereal products. Journal of the Science of Food and Agriculture 34: 1423-1426.

International Organization for Standardization (ISO), 1999. ISO 6492 - Animal feeding stuffs - Determination of fat content. Available at: https://www.iso.org/standard/12865.html.

International Organization for Standardization (ISO), 2002. ISO 5984 - Animal feeding stuffs - Determination of crude ash. Available at: https://www.iso.org/standard/37272.html.

International Organization for Standardization (ISO), 2009a. ISO 5983-2 - Animal feeding stuffs - Determination of nitrogen content and calculation of crude protein content - Part 2: Block digestion and steam distillation method. Available at: https://www.iso.org/ standard/52199.html.

International Organization for Standardization (ISO), 2009b. ISO 30024 - Animal feeding stuffs - determination of phytase activity. Available at: https://www.iso.org/standard/45787.html.

Kühn, I. and Partanen, K., 2012. Phytase improves apparent total tract digestibility of phosphorus and calcium in piglets fed diets with adequate or reduced phosphorus content. Journal of Animal Science 90: 194-196.

Kühn, I., Schollenberger, M. and Männer, K., 2016. Effect of dietary phytase level on intestinal phytate degradation and bone mineralization in growing pigs. Journal of Animal Science 94: 264267.

Leyva-Jimenez, H., Alsadwi, A.M., Gardner, K., Voltura, E. and Bailey, C.A., 2019. Evaluation of high dietary phytase supplementation on performance, bone mineralization, and apparent ileal digestible energy of growing broilers. Poultry Science 98: 811-819.

Myers, W.D., Ludden, P.A., Nayigihugu, V. and Hess, B.W., 2004. A procedure for the preparation and quantitative analysis of samples for titanium dioxide. Journal of Animal Science 82: 179-183.

R Core Team, 2017. R: a language and environment for statistical computing. R Foundation for Statistical Computing, Vienna, Austria.

Rodriguez, E., Han, Y. and Leil, X., 1999. Cloning, sequencing, and expression of an Escherichia coli acid phosphatase/phytase gene (appA2) isolated from pig colon. Biochemical and Biophysical Research Communications 257: 117-123.

Rutherfurd, S.M., Chung, T.K. and Moughan, P.J., 2014. Effect of microbial phytase on phytate $\mathrm{P}$ degradation and apparent digestibility of total $\mathrm{P}$ and $\mathrm{Ca}$ throughout the gastrointestinal tract of the growing pig. Journal of Animal Science 92: 189-197.

Schlegel, P. and Gutzwiller, A., 2016. Effect of dietary calcium level and source on mineral utilisation by piglets fed diets containing exogenous phytase. Journal of Animal Physiology and Animal Nutrition 101: 165-174

Selle, P.H., Cowieson, A.J., Cowieson, N.P. and Ravindran, V., 2012. Protein-phytate interactions in pig and poultry nutrition: a reappraisal. Nutrition Research Reviews 25: 1-17.

Torrallardona, D. and Ader, P., 2016. Effects of a novel 6-phytase (EC 3.1. 3.26) on performance, phosphorus and calcium digestibility, and bone mineralization in weaned piglets. Journal of Animal Science 94: 194-197. 


\section{De Cuyper et al.}

Velayudhan, D.E., Heo, J.M., Dersjant-Li, Y., Owusu-Asiedu, A. and Nyachoti, C.M., 2015. Efficacy of novel 6-phytase from Buttiauxella sp. on ileal and total tract nutrient digestibility in growing pigs fed a corn-soy based diet. Animal Feed Science and Technology 210: $217-224$
Zeng, Z., Li, Q., Tian, Q., Zhao, P., Xu, X., Yu, S. and Piao, X., 2015. Super high dosing with a novel Buttiauxella phytase continuously improves growth performance, nutrient digestibility, and mineral status of weaned pigs. Biological Trace Element Research 168: 103-109. 